\title{
Study of agricultural export prospects
}

\author{
Anna Solonenko ${ }^{1, *}$, Lyudmila Medvedeva ${ }^{2}$ and Yuliya Mostovaya $^{3}$ \\ ${ }^{1}$ Dmitrov Fisheries Technological Institute, 36, 141821, village Rybnoye, Moscow region, Russia \\ ${ }^{2}$ Don State Technical University, 1, Gagarin sg., 344003, Rostov-on-Don, Russia \\ ${ }^{3}$ Astrakhan State Technical University, 16, Tatishcheva str., 414000, Astrakhan, Russia
}

\begin{abstract}
The issues concerning the study of prospects of agricultural products export are considered in the article, including working out a strategic plan of Russian seafood export development. The analysis of revealed priority export markets for fish and fish products is conducted using a number of indicators in order to work out the encouragement and support tools of development of fish and seafood export from Russian Federation. The basic mechanisms of state support of seafood export development are described as one of the priority guidelines of agroindustrial complex development.
\end{abstract}

\section{Introduction}

In the context of modern economy strategic development, it is agricultural export that can be considered as the most important indice of growth and stability. There is a need to achieve the agricultural export level of at least $20 \%$ of GDP, which will promote the improvement of Russian economy competitive positions [1-4].

The principal aim of this study is to identify the prospects of Russian fish and seafood export since the given segment grows rapidly and becomes attractive for outer market.

At present, there has been an active development of techniques of the fishing export sector enhancement, which include capturing of new geographical supply directions and increase of processed products share. However, the volume of processed production depends on the investment environment in the country, which is one of the problems having a negative effect on export development in Russia. The following equally important challenges are also highlighted [5]:

- insufficient state support of the fish and seafood export merchants;

- poor development of transport and logistics networks;

- high degree of industry fixed assets depreciation;

- strong administrative burdens.

Let us specificate in Table 1 the problems affecting the development of the fish and seafood products export from Russian Federation.

\footnotetext{
${ }^{*}$ Corresponding author: ansolonenko@yandex.ru
} 
Table 1. Analysis of the problems of fish and seafood products export from Russian Federation.

\begin{tabular}{|c|c|}
\hline Section & Problem \\
\hline \multirow[t]{5}{*}{ Ship-building industry } & At present fishing vessel building is not a priority area. \\
\hline & $\begin{array}{l}\text { The fishing fleet capacity is reducing. These days the fleet is } \\
\text { reinforced mainly by the used foreign ships. }\end{array}$ \\
\hline & $\begin{array}{l}\text { There remains high degree of production capabilities } \\
\text { depreciation (both moral and physical). }\end{array}$ \\
\hline & $\begin{array}{l}\text { The production infrastructure makes it impossible to build } \\
\text { vessels or ships using large-sized blocks. }\end{array}$ \\
\hline & $\begin{array}{l}\text { The lack of large construction sites limits the possibility of } \\
\text { large-capacity ships and vessels building. }\end{array}$ \\
\hline \multirow[t]{4}{*}{$\begin{array}{l}\text { Fish and seafood producing } \\
\text { industry }\end{array}$} & $\begin{array}{l}\text { The Russian fishing fleet includes more than } 2,000 \text { vessels } \\
\text { with high depreciation degree. }\end{array}$ \\
\hline & $\begin{array}{l}\text { The lack of investment quotas does not contribute to the } \\
\text { fishery development of Russian Federation. }\end{array}$ \\
\hline & $\begin{array}{l}\text { The productivity of the current fishing fleet is limited by the } \\
\text { design features of the vessels and possibility of only slight } \\
\text { improvements. }\end{array}$ \\
\hline & $\begin{array}{l}\text { The critical lack of the latest capacities with temperature } \\
\text { conditions for cargo storage. }\end{array}$ \\
\hline \multirow[t]{2}{*}{$\begin{array}{l}\text { Fish and seafood processing } \\
\text { industry }\end{array}$} & $\begin{array}{l}\text { The fish processing enterprises capacity utilization makes up } \\
\text { about } 60 \% \text {. }\end{array}$ \\
\hline & $\begin{array}{l}\text { Limitations of freezing and processing capacities with } \\
\text { predominantly manual labor. }\end{array}$ \\
\hline
\end{tabular}

The problems identified have led us to conclusion that it is necessary to develop measures which will give the opportunity to propel the export of fish and seafood products from Russian Federation to the next level.

\section{Materials and methods}

Before discussing the prospects of fish and seafood products export, it is required to represent the statistical investigations that express the potential capacity of seafood production in Russia [6].

The fishing fleet is the centrepiece of capabilities for fish and seafood extraction. It amounts to more than $70 \%$ of the industry fixed production assets and provides more than $90 \%$ of the total catch. More than $92 \%$ of the total volume of frozen products, more than $96 \%$ of fish-flour and about $15 \%$ of canned products are produced on the vessels [7-9].

Let us consider the condition of Russian civil maritime fleet from 2015 to 2017 that showed quantitative decrease by $30 \%$ (Table 2 ).

Table 2. The number of marine vessels (indicator value per year, units).

\begin{tabular}{|c|c|c|c|}
\hline Vessel type & $\mathbf{2 0 1 5}$ & $\mathbf{2 0 1 6}$ & $\mathbf{2 0 1 7}$ \\
\hline Fishing base-ships and fish-transport vessels & 26 & 24 & 22 \\
\hline Fishing vessels & 843 & 838 & 820 \\
\hline Support ships, tending vessels & 42 & 43 & 49 \\
\hline Research vessels & 75 & 76 & 74 \\
\hline
\end{tabular}

For the period from 2015 to 2017 fishing vessels (the largest group) felt more than by one half. Under conditions of economic crisis, the ship owners in countries with developed fishing industry (Iceland, Norway, EU, and others) refocused in a substantial way on improving of existing vessels instead of building new ones. Due to this decision, the 
lifetime of vessels cost-efficient operation was significantly increased. The market of ship technical maintenance, modernization and repair services is also developed in mentioned countries. At the same time, Russian fleet needs to be improved and updated in order to increase fishing economic efficiency by reducing fuel consumption, engine noise, increasing the speed of the vessels with fishing gear and others, as well as making the vessel operation key indicators consistent with international requirements [10-11].

Let us consider the dynamics of fish and seafood production in Russian Federation (Table 3).

Table 3. The volume of fish and seafood production, thousand tons.

\begin{tabular}{|c|c|c|c|c|}
\hline Products & $\mathbf{2 0 1 5}$ & $\mathbf{2 0 1 6}$ & $\mathbf{2 0 1 7}$ & $\begin{array}{c}\mathbf{2 0 1 7} \\
\text { as a percentage } \\
\text { of 2016, \%o }\end{array}$ \\
\hline $\begin{array}{c}\text { Live, fresh or chilled fish } \\
\text { Non-frozen shell fish (not fish-farming } \\
\text { production) }\end{array}$ & 1176 & 1341 & 1368 & 102 \\
\hline $\begin{array}{c}\text { Fresh or chilled fish fillet, other fish flesh } \\
\text { (including comminuted fish) }\end{array}$ & 18.8 & 20.7 & 18.1 & 87.4 \\
\hline Frozen fish & 2897 & 3007 & 3057 & 101.7 \\
\hline Frozen fish fillet & 123 & 141 & 145 & 102.8 \\
\hline Dried fish, salted and unsalted or in brine & 49.1 & 47.3 & 106 & 224.1 \\
\hline Smoked fish (including fish fillet) & 57.2 & 53.0 & 58.4 & 110.2 \\
\hline Frozen shell fish & 44.4 & 50.3 & 69.9 & 138.9 \\
\hline
\end{tabular}

For the period from 2015 to 2017 there has been observed the increase of production volume of all types of fish products. The largest increase is seen in the sector of dried and salted fish production (by 2.24 times). The indicators of fish production volume dynamics are shown in Table 4.

Table 4. The indicators of fish and seafood production dynamics for the period 2015-2017.

\begin{tabular}{|c|c|c|c|c|}
\hline Products & $\begin{array}{c}\text { Production } \\
\text { average, } \\
\text { thousand tons }\end{array}$ & $\begin{array}{c}\text { Annual average } \\
\text { absolute growth } \\
\text { (reduction), } \\
\text { thousand tons }\end{array}$ & $\begin{array}{c}\text { Annual } \\
\text { average } \\
\text { growth } \\
\text { rate, \% }\end{array}$ & $\begin{array}{c}\text { Annual average } \\
\text { rate of increment } \\
\text { of growth } \\
\text { (reduction), \% }\end{array}$ \\
\hline $\begin{array}{c}\text { Live, fresh or } \\
\text { chilled fish }\end{array}$ & 1307 & 31 & 104.4 & 4.4 \\
\hline $\begin{array}{c}\text { Non-frozen shell } \\
\text { fish (not fish- } \\
\text { farming } \\
\text { production) }\end{array}$ & 54.5 & 4.2 & 114.9 & 14.9 \\
\hline $\begin{array}{c}\text { Fresh or chilled } \\
\text { fish fillet, other } \\
\text { fish flesh } \\
\text { (including } \\
\text { comminuted fish) }\end{array}$ & 18.2 & 0.2 & 102 & 2 \\
\hline Frozen fish & 2845 & 55.4 & 103.5 & 3.5 \\
\hline Frozen fish fillet & 110 & 10.5 & 119.3 & 19.3 \\
\hline $\begin{array}{c}\text { Dried fish, salted } \\
\text { and unsalted or in } \\
\text { brine }\end{array}$ & 60 & 8 & 120.6 & 20.6 \\
\hline $\begin{array}{c}\text { Smoked fish } \\
\text { (including fish } \\
\text { fillet) }\end{array}$ & 59 & 0.18 & 100.6 & 0.6 \\
\hline Frozen shell fish & 39 & 6.9 & 134.3 & 34.3 \\
\hline
\end{tabular}


The annual average increase of production of live, fresh or chilled fish amounts to 31 thousand tons $(4.4 \%)$, frozen fish - 55.4 thousand tons $(3.5 \%)$, fish fillet -10.5 thousand tons $(19.3 \%)$.

It is important to compare these indicators with the world industrial fishing volume (Table 5).

In 2016 the world industrial fishing volume amounted to 90.9 million tons, which is little less than in 2015. The catch rates in the seas and inland waters are $87.2 \%$ and $12.8 \%$ of the total catch, respectively.

The marine fisheries production volume amounted to 79.27 million tons in 2016. The largest decrease of the marine fisheries production volume is observed in Peru by $54.08 \%$, in Chile - by $51.31 \%$, in Thailand - by $49.43 \%$, and in Iceland - by $46.46 \%$. China, Indonesia, Vietnam, Russia, India, Malaysia, Morocco, Denmark and Ecuador increased the marine fisheries production volume in 2016.

Table 5. The indicators of the dynamics of marine fisheries production volume for a series of years.

\begin{tabular}{|l|c|c|c|c|}
\hline $\begin{array}{c}\text { Country / } \\
\text { territory }\end{array}$ & $\begin{array}{c}\text { Average } \\
\text { production volume } \\
\text { of marine fisheries, } \\
\text { million tons }\end{array}$ & $\begin{array}{c}\text { Annual average } \\
\text { absolute growth } \\
\text { (reduction), } \\
\text { million tons }\end{array}$ & $\begin{array}{c}\text { Annual } \\
\text { average } \\
\text { growth } \\
\text { rate, \% }\end{array}$ & $\begin{array}{c}\text { Annual average } \\
\text { rate of increment } \\
\text { of growth (+) } \\
\text { /reduction (-), \% }\end{array}$ \\
\hline China & 14.5 & 0.34 & 103 & 3 \\
\hline Indonesia & 5.8 & 0.15 & 103.4 & 3.4 \\
\hline USA & 5.0 & -0.05 & 98.8 & -1.2 \\
\hline Peru & 5.2 & -0.89 & 82.3 & -17.7 \\
\hline Russia & 4.1 & 0.09 & 102.8 & 2.8 \\
\hline Japan & 3.53 & -0.12 & 95.9 & -4.1 \\
\hline India & 3.4 & 0.07 & 102.5 & 2.5 \\
\hline Chile & 2.14 & -0.31 & 83.5 & -16.5 \\
\hline Vietnam & 2.4 & 0.21 & 113.0 & 13.0 \\
\hline Burma & 1.8 & 0.03 & 103 & 3.0 \\
\hline Norway & 2.23 & -0.1 & 94.6 & -5.4 \\
\hline Philippines & 2.0 & -0.03 & 97.8 & -2.2 \\
\hline Republic of Korea & 1.6 & -0.05 & 95.6 & -4.4 \\
\hline Thailand & 1.7 & -0.26 & 84.4 & -15.7 \\
\hline Malaysia & 1.4 & 0.06 & 105.2 & 5.2 \\
\hline Mexico & 1.37 & 0.01 & 101.2 & 1.2 \\
\hline Iceland & 1.37 & -0.18 & 85.5 & -14.5 \\
\hline Morocco & 1.23 & 0.10 & 112.0 & 12.0 \\
\hline Total in the world & 80.9 & -0.67 & 99.0 & -1.0 \\
\hline
\end{tabular}

The world volume of marine fisheries production reaches 80.9 million tons at the average with the annual average reduction of $1 \%$. The largest annual average increase of marine fisheries production volume is observed in Vietnam (by 13\%), Morocco (by 12\%), Malaysia (by 5.2\%), Indonesia (by 3.4\%) and China (3\%). The largest decrease of annual average absolute growth and growth rates is observed in Peru, Chile, Thailand and Iceland.

\section{Results}

The analysis of statistical data demonstrated that Russian fishing industry market has high export potential. However, it is necessary to create mechanisms of efficient implementation of export transactions, the most important of which, in our view, include the following:

1. Development and implementation of export transactions insurance scheme.

2. Organization of the efficient export logistic network.

3. Organization of stock exchanges for export products electronic trading. 
4. Branding of fish and seafood products.

5. Development of system of export transactions regulatory support and so on.

Let us review the mechanism of development and implementation of export transactions insurance scheme in further detail.

Currently the system of fish and seafood export insurance is not developed in Russia $[12,13]$.

The organization of such system is seen as follows, taking into account international practices. Insurance should be carried out by the government agency, which functions are similar to China's Sinosure. The powers of the existing Eksar agency should be expanded for this purpose $[14,15]$. The separate division for fish and seafood insurance can be organized in the agency. The functions of the division may also include interaction with the regulatory authorities of foreign countries and counterparts of insuring parties in order to settle economic disputes and reduce the impact of political risks.

Table 6. Suggested insurance lines.

\begin{tabular}{|c|c|c|}
\hline Risks & Insurance lines & Note \\
\hline $\begin{array}{l}\text { It is quite difficult to insure } \\
\text { the catch-failure for a fishing } \\
\text { company that has its own } \\
\text { vessels and quotas because } \\
\text { of the high degree of wear of } \\
\text { vessels with useful lifetime } \\
\text { of more than } 25 \text { years. }\end{array}$ & $\begin{array}{l}\text { Insurance of transport } \\
\text { vessels with application } \\
\text { of rates and deductible } \\
\text { franchise. } \\
\text { Additionally, the } \\
\text { introduction of } \\
\text { government guarantees. }\end{array}$ & $\begin{array}{l}\text { The smaller is the deductible under } \\
\text { the insurance contract, the higher } \\
\text { is the insurance rate and vice } \\
\text { versa. }\end{array}$ \\
\hline $\begin{array}{l}\text { No insurance of medium- } \\
\text { term and long-term } \\
\text { contracts. }\end{array}$ & $\begin{array}{l}\text { Insurance of medium- } \\
\text { term and long-term } \\
\text { contracts. }\end{array}$ & $\begin{array}{l}\text { For medium-term and long-term } \\
\text { contracts the insurance coverage } \\
\text { can be provided in the amount of } \\
\text { no more than } 85 \% \text { of the contract } \\
\text { value. If foreign producers } \\
\text { participate in the project, the } \\
\text { interests of Russian participants of } \\
\text { the export contract are protected in } \\
\text { the first place. }\end{array}$ \\
\hline $\begin{array}{l}\text { Incurrence of political risks } \\
\text { as a consequence of putting } \\
\text { fish products in the sanctions } \\
\text { list. } \\
\text { The risk can cause increase } \\
\text { of costs and loss of profit. }\end{array}$ & $\begin{array}{l}\text { Insurance of financial } \\
\text { losses upon incurrence of } \\
\text { political risks. }\end{array}$ & $\begin{array}{l}\text { Insurance of financial losses upon } \\
\text { incurrence of political risks with } \\
\text { compensation of } 85 \% \text { of the } \\
\text { insurance company's expenses } \\
\text { when paying insurance indemnity. }\end{array}$ \\
\hline Exporter's payment risk. & $\begin{array}{l}\text { Use of documentary } \\
\text { credits consistent with } \\
\text { UCP } 600 \text { ("Uniform } \\
\text { Customs and Practice for } \\
\text { Documentary Credits", } \\
\text { developed by ICC). }\end{array}$ & $\begin{array}{l}\text { The bank service that allows not to } \\
\text { be concerned about the outcome of } \\
\text { the large-scale deal. Sberbank } \\
\text { takes the responsibility for } \\
\text { transaction payments settlement: } \\
\text { the seller is confident that he will } \\
\text { receive the money, the customer is } \\
\text { confident that he will receive the } \\
\text { goods. }\end{array}$ \\
\hline $\begin{array}{l}\text { Instability (growth) of the } \\
\text { ruble exchange rate. }\end{array}$ & $\begin{array}{l}\text { Forex hedging by means } \\
\text { of forward contracts or } \\
\text { non-stop options for } \\
\text { currency sale. }\end{array}$ & $\begin{array}{l}\text { When choosing a forward contract, } \\
\text { the exporting company does not } \\
\text { spend its funds, but is obliged to } \\
\text { sell the currency at the exchange } \\
\text { rate defined by the contract, and } \\
\text { place cash collateral on bank } \\
\text { deposit. Thus, companies focusing } \\
\text { on the export of goods get better }\end{array}$ \\
\hline
\end{tabular}




\begin{tabular}{|c|c|c|}
\hline & & protection from exchange risks. \\
\hline $\begin{array}{l}\text { Logistical risk is one of the } \\
\text { most significant in the export } \\
\text { of fish and seafood products. } \\
\text { Even slight changes of terms } \\
\text { of delivery or storage } \\
\text { conditions can lead to } \\
\text { damage or loss of the } \\
\text { product, which is the main } \\
\text { logistical risk, causing huge } \\
\text { losses. }\end{array}$ & $\begin{array}{l}\text { Cargo insurance while } \\
\text { transporting and storing } \\
\text { goods. }\end{array}$ & $\begin{array}{l}\text { This insurance is organized as } \\
\text { follows: } \\
\text { - for each individual transport / } \\
\text { storage (the Policy of insurance is } \\
\text { issued); } \\
\text { - for each separate delivery parcel } \\
\text { (the Global Policy is issued); } \\
\text { - for the annual insurance period, } \\
\text { when any cargo is insured in line } \\
\text { with the annual agreement (Open } \\
\text { Cover Insurance Policy is issued). }\end{array}$ \\
\hline
\end{tabular}

The insurance terms may be as follows:

The insurance events include delayed payment of foreign contracting parties, as well as trade disputes.

The event is considered as insurable if the exporting company suffers financial losses from the specified events, while with due diligence complying with the terms of the contract, Russian legislation, international regulations and conventions along with the legislation of the country where the transactor is registered.

The rates for every insurance object are determined on the individual basis considering characteristics of the transactor, its registration country and current political situation. Insurance settlement payments are guaranteed by the government.

The term of the agreement is determined in accordance with the term of the contract.

The size of damage of exporting company is determined as the cost of lost property (the cost of repairing damaged property) and unpaid obligations of transactors.

Obligations under contracts are considered unpaid if the payment is delayed for more than six months. The property is considered lost if it is destroyed or expropriated and held by the foreign government or third parties for more than six months.

Final products are considered lost if they were expropriated by representatives of foreign countries and their cost was not refunded within three months.

Damages from unpaid obligations are determined as the value of unpaid obligations of foreign transactors, taking into account the fines and penalties stipulated in the contract by the time of insured event.

The damage in case of injury or withdrawal of property is determined on the basis of the balance sheet value or replacement cost of the property adjusted for depreciation by the time of insured event.

The damage in case of final products withdrawal is defined by the market value of the final products by the time of insured event.

The insurance indemnity is paid in the amount of up to $95 \%$ of damages for political risks and up to $90 \%$ of damages for trade risks (the deductible franchise is used).

\section{Conclusions}

Thus, the prospects of strengthening of Russian Federation in the cross-border market of fish and seafood products are related to solution of a number of problems:

- the lack of the export insurance system for fish and seafood supplies requires development of the unified system of fish and seafood export insurance along with reduction of risks of fish and seafood exporters;

- the lack of specific legal framework for implementation of export insurance of fish and seafood supplies requires establishment of uniform, comprehensible and translucid rules of export insurance; 
- underinvestment in the development of new fishing equipment requires the issuance of research concessions, in which the company can develop new concepts of fish ponds and apply prototypes without payment of license duty during 15 years;

- low level of awareness of fish exporting companies requires the explanatory work to inform companies about growth opportunities (including types and mechanisms of state support), information and consulting support of prospective exporters, development of competencies in the field of export activities via creation of special programs;

- the construction of fishing vessels is not priority task of industrial shipbuilding - the construction of 50 fishing vessels by 2023 will increase the volume of fish and seafood production by $50 \%$;

- the lack of skilled staff throughout fishing industry requires introduction of innovative management and training mechanisms to provide skilled staff for production and processing of fish products. Monitoring of human resourcing indicators and forecasting the industry's demand for personnel is also needed;

- insufficient development of price mechanisms. Development of the benchmark in the fishing industry, futures trading of "fish equivalent" can form specific pricing mechanism, recognized worldwide, raise additional investments in the fishing industry, broaden the range of products, and eventually create a center of world open trade of similar types of goods.

\section{References}

1. N. Reshetnikova, M. Magomedov, Smart Innovation, Systems and Technologies 138, 399-408 (2020)

2. T. Marwa, A. Bashir, M. Azwardi, H. Thamrin, International Journal of Economics and Business Administration 5(2), 69-82 (2017)

3. Z. Gornostaeva, Y. Sorokina, Lecture Notes in Networks and Systems 73, 177-184 (2020)

4. V. Joao, Science of The Total Environment 68820, 346-360 (2019)

5. K. Raupov, Bulletin of the Tajik National University. Series of Socio-Economic and Social Sciences 8, 131-135 (2019)

6. V. Mazur, K. Barmuta, S. Demin, E. Tikhomirov, M. Bykovskiy, International Journal of Economics and Financial 6(1S), 270-274 (2016)

7. I. Fedulova, O. Voronkova, P. Zhuravlev, E. Gerasimova, M. Glyzina, N. Alekhina, Entrepreneurship and Sustainability 7(2), 1059-1073 (2019)

8. Z. Gornostaeva, Lecture Notes in Networks and Systems 73, 287-295 (2020)

9. V. Borisova, E. Panfilova, P. Zhukov, S. Matulis, V. Matveev, V. Teymurova, International Journal of Management and Business Research 9(1), 158-169 (2019)

10. Z. Gornostaeva, I. Kushnaryova, E. Alekhina, Advances in Intelligent Systems and Computing 726, 207-216 (2019)

11. I. Krasyuk, Y. Medvedeva, Proceedings of the 33rd International Business Information Management Association Conference, IBIMA 2019: Education Excellence and Innovation Management through Vision 2020- 2019, 8807-8817 (2019)

12. Z. Gornostaeva, N. Lazareva, M. Bugaeva, O. Gribova, N. Zibrova, International Journal for Quality Research 13(2), 301-314 (2019)

13. I.Terenina, D. Kostoglodov, L. Kiyanova, O. Usatkina, International Journal of Economics and Business Administration 7, 325-338 (2019) 
14. O. Godina, Y. Kosenkova, L. Maksimenko, Y. Mezentseva, T. Shcherbakova, Advances in Intelligent Systems and Computing 726, 118-127 (2019)

15. N. Drozdov, M. Vasilenko, E. Kuzina, Y. Tagiltseva, Proceedings of the 2018 International Conference "Quality Management, Transport and Information Security, Information Technologies", 98-102 (2018) 